\title{
Technology transfer, climate change mitigation, and environmental patent impact on sustainability and economic growth: A comparison of European countries
}

\author{
João J.M. Ferreira ${ }^{\mathrm{a}, *}$, Cristina I. Fernandes ${ }^{\mathrm{a}}$, Fernando A.F. Ferreira ${ }^{\mathrm{b}, \mathrm{c}}$ \\ ${ }^{a}$ Department of Business and Economics \& NECE Research Unit, University of Beira Interior Estrada do Sineiro, 6200-209 Covilhã, Portugal \\ ${ }^{\mathrm{b}}$ ISCTE Business School, BRU-IUL, University Institute of Lisbon, Avenida das Forças Armadas, 1649-026 Lisbon, Portugal \\ ${ }^{\mathrm{c}}$ Fogelman College of Business and Economics, University of Memphis, Memphis, TN 38152-3120, United States
}

\section{A R T I C L E I N F O}

\section{Keywords:}

Climate change

Economic growth

European country

Environmental patent

Sustainability

Technology transfer

\begin{abstract}
A B S T R A C T
Most of the literature on technology transfer has tended to focus on the country or regional level, neglecting to look at the continent-level flow of knowledge that is becoming more important due to regional trading blocs. This study sought to fill the gap in research on the role of technology transfer in the European continent (i.e., countries inside and outside the Eurozone) by focusing on environment-related patents. The research also included examining the effects of environmental water-related adaptation technology and climate change mitigation patents on real gross domestic product. The results contribute to the literature on technology transfer policies by highlighting how environmental patents influence Europe's economic growth rate and whether countries' geographical location can affect their level of entrepreneurship and innovation. The technology-organization-environment (TOE) and sustainability perspectives were used as a theoretical framework for understanding how geographical contexts influence technology transfer in terms of environment-related patents. Implications for management, theory and policy are discussed together with the study's limitations and suggestions for future research.
\end{abstract}

\section{Introduction}

Solow (1956) argues that the relationship between innovation and growth in the long-term directly impacts economic growth. Various types of research have provided empirical support for this assertion (Bayarçelik and Taşel, 2012; Bektas et al., 2015; Freeman, 2002; Grossman and Helpman, 1994; Hasan and Tucci, 2010; Segerstrom, 1991; Wong et al., 2005). However, innovation and technology transfer can sometimes have negative impacts on the environment. The increasing use of innovations and technologies has thus become a major concern in terms of the price paid in damage to the environment (i.e., climate change). Technology transfer in international contexts commonly refers to the sale or licensing of intellectual property, but the term includes any process by which citizens of one country can access and utilize technology developed in another country (Mytelka, 2007).

To combat environmental impacts resulting in climate change, a significant majority of countries have adhered to the United Nations
Framework Convention on Climate Change (UNFCCC). This means they have agreed to implement practical measures to achieve the common goal of reducing global emissions of carbon dioxide (CO2) and other greenhouse gases. As a result, the number of environmentally friendly innovations has increased at a remarkable rate in recent decades (Su and Moaniba, 2017).

By definition, sustainable economic growth refers to any form of economic growth that does not harm the environment (Grimsley, 2016; Nino, 2016). With this concept in mind, various researchers have sought to understand the role of innovation in minimizing environmental impacts contributing to climate change. In addition, governments in various countries have developed programs to facilitate the development and diffusion of climate change mitigation technologies (Jong et al., 2016; Mowery et al., 2010; Watson et al., 2015). Some authors also have linked environmental issues to economics, growth and productivity (Albrizio et al., 2017; Dong et al., 2014; Jaffe and Palmer, 1997; Tucker, 1995), while others have examined the effect of innovation as a predictor of climate change in different scenarios

\footnotetext{
* Corresponding author.

E-mail addresses: jjmf@ubi.pt (J.J.M. Ferreira), cristina.isabel.fernandes@ubi.pt (C.I. Fernandes), fernando.alberto.ferreira@iscte.pt, fernando.ferreira@memphis.edu (F.A.F. Ferreira).
} 
(Moss et al., 2010).

This topic is considered of such importance that environmental innovation research is a cornerstone of the Europe 2020 strategy. The plan identifies smart, sustainable and inclusive growth technologies to help the European Union (EU) develop more sustainable resources to achieve a more competitive economy and provide high levels of employment, productivity and social cohesion. At least $60 \%$ of Horizon 2020 's overall budget is expected to be allocated to sustainable development (see http://ec.europa.eu/programmes/horizon2020/en/area/ environment-climate-action).

Much of the existing literature has studied this issue at the micro level, namely at the company level (Costantini and Liberati, 2014; Fabrizi et al., 2018; Youssef et al., 2018), so the present research sought to study environmental technology transfer in Europe and transfer effects on economic growth. Because European countries present different levels of economic growth and different degrees of environmental technology transfer (cf. Ferreira et al., 2018, 2019), we sought to divide these countries into two groups (i.e., Eurozone and nonEurozone European countries). This procedure aimed at identifying potential differences between groups, providing a better characterization of Europe in this study context. This research focused, therefore, on contributing to a better understanding of the problem of climate change, with a particular focus on how sustainable technological transfer contributes to economic growth. The study used country-level aggregated data based on statistics collected by the Organization for Economic Co-operation and Development (OECD) for different periods. This approach facilitated the confirmation of whether technology transfer, climate change mitigation, and environmental patents have an impact on sustainability and economic growth.

The results obtained support the conclusion that economic growth can be achieved with a more sustainable use of resources. Innovations can be made that contribute to countries' sustainable economic growth without harming the environment. Technological innovation can effectively respond to changes in key climatic conditions. We thus sought to contribute to knowledge about innovations in European contexts, which boost economic growth while protecting the environment.

This paper is structured as follows. Section two presents a literature review focused on sustainable technology transfer and economic growth. Section three presents the methodological aspects. The fourth section analyses the empirical results. The last section concludes the paper with a discussion of the study's contributions and limitations, as well as delineating opportunities for future research.

\section{Literature review}

\subsection{Impact of sustainable technology transfer on economic growth}

Fagerberg (1994) argues that productivity differences are responsible for variations in income between countries, with technology playing a key role in determining productivity. Keller (2010) further points out that, for most countries, foreign sources of technology transfer represent up to $90 \%$ of domestic productivity growth. Most of the world's technology creation occurs in developed countries, although technology transfer means these innovations can also affect the pattern of climate change in countries with strong constraints on technological innovation.

Some researchers assert that innovation is key to the sustainable development of all societies (Boons et al., 2013; Matos and Silvestre, 2013). Technological breakthroughs or the deployment of technologies that capture carbon would be crucial to controlling climate change (Chaudhry et al., 2013; Wennersten et al., 2015). However, according to Bagatin et al. (2014), not all kinds of innovations are desirable since technologies can have disastrous impacts on the environment. Various researchers have, therefore, emphasized sustainable innovation, which companies and policymakers can collectively develop by fostering their capability to create environmentally friendly solutions (Cainelli et al., 2015; Owen et al., 2013). Thus, sustainable innovation leads to socially desirable results (Stahl et al., 2013; Voegtlin and Scherer, 2017; Von Schomberg, 2011).

When countries accumulate technological capabilities and relevant innovations, this increases these nations' ability to engage in climate change mitigation not only as users of low-carbon technology but also as innovative producers (Bell, 2012; Ockwell et al., 2013). In contrast, the option of importing and installing sustainable technology is a quick solution that does little to help countries learn about the process of creating sustainable innovations. Creatively engaging underlying technologies contributes to nations' ability to lead-and adapt the practices involved in-sustainable development and, consequently, to promote economic growth (United Nations Conference on Trade and Development (see UNCTD, 2010).

Zollo et al. (2013) call attention to the importance of studying the "how" of sustainability (i.e., how to promote the development of sustainable innovations) rather than the "why" (i.e., why look for sustainable innovations) or the "what" (i.e., what sustainable innovations are). This, in turn, leads to the following question: How can the development and diffusion of sustainable technology transfer be promoted? In this regard, one should bear in mind that sustainable technology transfer is commonly considered a multidimensional process (cf. Chege et al., 2019), which encourages the use of innovations and begins with the development of innovations and progresses through their dissemination and implementation (cf. Global Mobility Report, 2017).

Effective, sustainable technology transfer thus requires an understanding of the knowledge, projects, and production systems that facilitate innovations and modifications (Ockwell et al., 2008; United Nations Center on Transnational Corporations (UNCTC), 1987). Technological transfer requires not only know-how but also know-why, namely, the deeper, specific, and systematic knowledge needed to manage technological change (Lundvall, 2011). Based on these insights, the present study's first research hypothesis was defined as follows: H1. Sustainable technology transfer has a positive impact on economic growth.

\subsection{Impact of climate change mitigation on economic growth}

The UNFCCC has sought to mitigate the intensifying effects of climate change. At the Conference of the Parties, signatories agreed in 2015 to limit the average increase in global temperatures to $2^{\circ}$ centigrade $\left({ }^{\circ} \mathrm{C}\right.$ ) above pre-industrial levels by 2020 (UNFCCC, 2015). While most member states agreed to $2^{\circ} \mathrm{C}$, the convention emphasized that the efforts to reduce average temperatures should go even further and limit them to $1.5^{\circ} \mathrm{C}$ (McSweeney and Pidcock, 2015). This objective can be achieved mainly by limiting global annual emissions of gases that most scientists believe are the main cause of climate change (Oreskes, 2004).

Emissions of $\mathrm{CO} 2$ make up by far the largest volume of greenhouse gases emitted (Environmental Protection Agency (EPA), 2016). The UNFCCC's goal requires a serious commitment from countries to prioritizing the reduction of $\mathrm{CO} 2$ emissions. In this context, the development and implementation of environmentally friendly technologies are fundamental, and these are high on the list of many actions countries need to take to achieve the $2^{\circ} \mathrm{C}$ target (Su and Moaniba, 2017).

Various authors consider understanding the role of innovation crucial to minimizing environmental impacts leading to climate change. An essential part of this process is the various programs that governments have established to facilitate the development and diffusion of climate change mitigation technologies (De Marchi and Grandinetti, 2013; Hall and Clark, 2003; Jong et al., 2016; Watson et al., 2015). Other researchers have linked environmental issues to economic growth and productivity (Dong et al., 2014; Grossman and Krueger, 1995; Jaffe and Palmer, 1997; Porter and Van der Linde, 1995; Tucker, 1995), as well as forecasting climate change's impacts in different scenarios (Moss et al., 2010). However, the 
literature has mostly focused on analyzing the relationship between green technologies and pollutant emissions from the perspective of how the former affect the latter in terms of climate change (Goodall, 2008). Various studies have sought to determine key policy drivers and incentives that foster environmental innovations. For instance, Grubb (2004) emphasizes the crucial role of technologies in combating climate change. The cited author argues that climate change cannot be reversed with a single formula but instead a variety of options need to be applied by different sectors.

In addition, Mowery et al. (2010) contend that the nature of policies required to combat climate change may differ from sector to sector in terms of technological developments and implementations. Veugelers (2012) also found that fiscal incentives are highly motivating factors leading to sustainable technological transfer in some sectors of activity. Peters et al. (2012), unlike other researchers, failed to find any evidence that policies encouraging sustainable technology can stimulate innovative production. Similar to Antonioli et al. (2013), Peters et al. (2012) argue that technology-boosting policies in one country do not necessarily have the same impact when applied to other nations' realities. Nonetheless, the creation and use of sustainable technologies promoting economic growth has been the focus of various studies (Ashford et al., 1985; Blazejczak et al., 2000; Haselip et al., 2015; Norberg-Bohm, 1999). Solomon et al. (2009) suggest that researchers need to understand better the role of environmental innovations in combating climate change and subsequently promoting sustainable economic growth.

To this end, experts must consistently monitor the success and progress of these innovations and the programs that use them (Barron and McJeon, 2015). Therefore, combating the effects of climate change through mitigation and adaptation technologies requires research on and development of new technologies, as well as these innovations' soft diffusion (Wiesenthal et al., 2012). The present study's second research hypothesis was thus defined as follows:

H2. Climate change mitigation technology has a positive impact on sustainable economic growth.

\section{Methodology}

\subsection{Data}

This research used country-level aggregate data collected by the OECD (https://stats.oecd.org/) as environment, population, international trade, labor and national accounts statistics between 2000 and 2013 for 23 countries, corresponding to 291 observations (i.e., an unbalanced panel). Table 1 shows the countries and years used in the present study.

\subsection{Measures}

\subsubsection{Dependent variable}

This study included real gross domestic product (GDP) growth (i.e., annual growth in percentage) as a dependent variable. Real GDP was thus used as a measure of economic growth.

\subsubsection{Predictor variables}

3.2.2.1. Control variables. The control variables used in the analysis included population growth rates (i.e., annual growth in percentage) and GDP per capita (i.e., in thousands of euros $(€)$ and constant prices). Other variables were current account balances (i.e., as a percentage of GDP) and total hours worked growth (i.e., annual growth). The selection of variables was supported by the studies presented in Table 2.

3.2.2.2. Technology transfer (patent variables). Regarding technology transfer variables, we used environment-related technology patents (i.e., number per million inhabitants). Environmental management patents and water-related adaptation technology patents (i.e., number per million inhabitants) served as proxies for sustainable technology transfer. Climate change mitigation technology (i.e., number per million inhabitants) was the proxy for climate change mitigation patents. Table 2 shows an overview of the variables used in the study.

\subsection{Data analysis}

The econometric analysis used to assess patents' impact on GDP growth-particularly those linked to environmental issues-was based on multiple regression models of panel data. Values for the 23 countries under study were estimated using fixed effects models. Thus, the following eight econometric models were applied:

$$
\begin{aligned}
-G R= & \alpha_{0}+\alpha_{1} P O P \_G R+\alpha_{2} G D P \_P H+\alpha_{3} C A B+\alpha_{4} T H W \_G R \\
& +\alpha_{5} E U R
\end{aligned}
$$

$G D P \_G R=\alpha_{0}+\alpha_{1} P O P \_G R+\alpha_{2} G D P \_P H+\alpha_{3} C A B+\alpha_{4} T H W \_G R$

$$
\begin{aligned}
G D P_{G R}= & \alpha_{0}+\alpha_{1} P O P_{G R}+\alpha_{2} G D P_{P H}+\alpha_{3} C A B+\alpha_{4} T H W_{G R}+\alpha_{5} E U R \\
+ & \alpha_{6} P A T_{E N V} \\
G D P \_G R= & \alpha_{0}+\alpha_{1} P O P \_G R+\alpha_{2} G D P \_P H+\alpha_{3} C A B+\alpha_{4} T H W \_G R \\
& +\alpha_{5} E U R+\alpha_{6} P A T \_E N V \times E U R \\
G D P \_G R= & \alpha_{0}+\alpha_{1} P O P \_G R+\alpha_{2} G D P \_P H+\alpha_{3} C A B+\alpha_{4} T H W \_G R \\
& +\alpha_{5} P A T \_E N V \\
G D P \_G R= & \alpha_{0}+\alpha_{1} P O P \_G R+\alpha_{2} G D P \_P H+\alpha_{3} C A B+\alpha_{4} T H W \_G R \\
& +\alpha_{5} E U R+\alpha_{6} P \\
A T \_E N V \_M A N & +\alpha_{7} P A T \_E N V \_W A T+\alpha_{8} P A T \_E N V \_C L I M
\end{aligned}
$$

$$
\begin{gathered}
G D P \_G R=\alpha_{0}+\alpha_{1} P O P \_G R+\alpha_{2} G D P \_P H+\alpha_{3} C A B+\alpha_{4} T H W \_G R \\
+\alpha_{5} E U R+\alpha_{6} P A T \_E N V \_M A N \times E U R \\
+\alpha_{7} P A T \_E N V \_W A T \times E U R+\alpha_{8} P A T \_E N V \_C L I M \times E U R
\end{gathered}
$$

$$
\begin{aligned}
G D P \_G R= & \alpha_{0}+\alpha_{1} P O P \_G R+\alpha_{2} G D P \_P H+\alpha_{3} C A B+\alpha_{4} T H W \_G R \\
& +\alpha_{5} P A T \_E N V \_M A N+\alpha_{6} P A T \_E N V \_W A T \\
& +\alpha_{7} P A T \_E N V \_C L I M
\end{aligned}
$$

For all these estimations, the existence of multicollinearity between exogenous variables (i.e., the variance inflation factor (VIF)) was tested, and robust standard errors were calculated for the coefficients to eliminate the possibility of heteroscedasticity. The data was analyzed using Stata version 12.0 software.

\section{Results and discussion}

\subsection{Statistics}

Table 3 shows the descriptive statistics and correlation coefficients for the endogenous variables used in the econometric modeling and VIF. Notably, no variables with multicollinearity effects (VIF $<10$ ) were found.

Table 4 presents the results for the different models estimated for the entire sample and for Europe and the Eurozone. For the entire sample and European countries sample, the models have good predictive power, with adjusted R-squared values between 0.540 and 0.570. The three models estimated for the Eurozone have weak to moderate predictive power, with adjusted R-squared values between 0.217 and 0.413 . 
Table 1

Countries and years.

\begin{tabular}{|c|c|c|c|c|c|c|c|c|c|c|c|c|c|c|}
\hline & 2000 & 2001 & 2002 & 2003 & 2004 & 2005 & 2006 & 2007 & 2008 & 2009 & 2010 & 2011 & 2012 & 2013 \\
\hline Czech Republic & $\mathrm{x}$ & $\mathrm{x}$ & $\mathrm{X}$ & $\mathrm{x}$ & $\mathrm{x}$ & $\mathrm{x}$ & $\mathrm{x}$ & $\mathrm{x}$ & $\mathrm{x}$ & $\mathrm{X}$ & $\mathrm{x}$ & $\mathrm{x}$ & $\mathrm{x}$ & $\mathrm{x}$ \\
\hline Denmark & & & & & & $\mathrm{x}$ & $\mathrm{x}$ & $\mathrm{x}$ & $\mathrm{x}$ & $\mathrm{X}$ & $\mathrm{x}$ & $\mathrm{x}$ & $\mathrm{x}$ & $\mathrm{x}$ \\
\hline Hungary & $\mathrm{x}$ & $\mathrm{x}$ & $\mathrm{X}$ & $\mathrm{X}$ & $\mathrm{x}$ & $\mathrm{x}$ & $\mathrm{x}$ & $\mathrm{x}$ & $\mathrm{x}$ & $\mathrm{X}$ & $\mathrm{x}$ & $\mathrm{x}$ & $\mathrm{x}$ & $\mathrm{x}$ \\
\hline Netherlands & & & & & $\mathrm{x}$ & $\mathrm{x}$ & $\mathrm{x}$ & $\mathrm{x}$ & $\mathrm{x}$ & $\mathrm{X}$ & $\mathrm{x}$ & $\mathrm{x}$ & $\mathrm{x}$ & $\mathrm{x}$ \\
\hline Norway & $\mathrm{x}$ & $\mathrm{x}$ & $\mathrm{X}$ & $\mathrm{X}$ & $\mathrm{x}$ & $\mathrm{x}$ & $\mathrm{x}$ & $\mathrm{x}$ & $\mathrm{x}$ & $\mathrm{X}$ & $\mathrm{x}$ & $\mathrm{x}$ & $\mathrm{x}$ & $\mathrm{x}$ \\
\hline Poland & & & & & $\mathrm{x}$ & $\mathrm{x}$ & $\mathrm{x}$ & $\mathrm{x}$ & $\mathrm{x}$ & $\mathrm{X}$ & $\mathrm{x}$ & $\mathrm{x}$ & $\mathrm{x}$ & - \\
\hline Sweden & $\mathrm{x}$ & $\mathrm{x}$ & $\mathrm{X}$ & $\mathrm{x}$ & $\mathrm{x}$ & $\mathrm{x}$ & $\mathrm{x}$ & $\mathrm{x}$ & $\mathrm{x}$ & $\mathrm{X}$ & $\mathrm{x}$ & $\mathrm{x}$ & $\mathrm{x}$ & $\mathrm{x}$ \\
\hline Switzerland & $\mathrm{x}$ & $\mathrm{x}$ & $\mathrm{X}$ & $\mathrm{x}$ & $\mathrm{x}$ & $\mathrm{x}$ & $\mathrm{x}$ & $\mathrm{x}$ & $\mathrm{x}$ & $\mathrm{X}$ & $\mathrm{x}$ & $\mathrm{x}$ & & \\
\hline $\begin{array}{l}\text { United Kingdom } \\
\text { Eurozone }\end{array}$ & $\mathrm{x}$ & $\mathrm{x}$ & $\mathrm{X}$ & $\mathrm{x}$ & $\mathrm{x}$ & $\mathrm{x}$ & $\mathrm{x}$ & $\mathrm{x}$ & $\mathrm{x}$ & $\mathrm{X}$ & $\mathrm{x}$ & $\mathrm{x}$ & $\mathrm{x}$ & $\mathrm{x}$ \\
\hline Austria & $\mathrm{x}$ & $\mathrm{X}$ & $\mathrm{X}$ & $\mathrm{x}$ & $\mathrm{x}$ & $\mathrm{x}$ & $\mathrm{x}$ & $\mathrm{x}$ & $\mathrm{x}$ & $\mathrm{X}$ & $\mathrm{x}$ & $\mathrm{x}$ & $\mathrm{x}$ & $\mathrm{X}$ \\
\hline Belgium & & & & $\mathrm{x}$ & $\mathrm{x}$ & $\mathrm{x}$ & $\mathrm{x}$ & $\mathrm{x}$ & $\mathrm{x}$ & $\mathrm{X}$ & $\mathrm{x}$ & $\mathrm{x}$ & $\mathrm{x}$ & \\
\hline Estonia & & $\mathrm{x}$ & $\mathrm{x}$ & $\mathrm{x}$ & $\mathrm{x}$ & $\mathrm{x}$ & $\mathrm{x}$ & $\mathrm{x}$ & $\mathrm{x}$ & $\mathrm{X}$ & $\mathrm{x}$ & $\mathrm{x}$ & $\mathrm{x}$ & $\mathrm{X}$ \\
\hline Finland & $\mathrm{x}$ & $\mathrm{x}$ & $\mathrm{x}$ & $\mathrm{x}$ & $\mathrm{x}$ & $\mathrm{x}$ & $\mathrm{x}$ & $\mathrm{x}$ & $\mathrm{x}$ & $\mathrm{X}$ & $\mathrm{x}$ & $\mathrm{x}$ & $\mathrm{x}$ & $\mathrm{X}$ \\
\hline France & $\mathrm{x}$ & $\mathrm{x}$ & $\mathrm{x}$ & $\mathrm{x}$ & $x$ & $\mathrm{x}$ & $\mathrm{x}$ & $\mathrm{x}$ & $\mathrm{x}$ & $\mathrm{X}$ & $\mathrm{x}$ & $\mathrm{x}$ & $\mathrm{x}$ & $\mathrm{X}$ \\
\hline Germany & $\mathrm{x}$ & $\mathrm{x}$ & $\mathrm{x}$ & $\mathrm{x}$ & $\mathrm{x}$ & $\mathrm{x}$ & $\mathrm{x}$ & $\mathrm{x}$ & $\mathrm{x}$ & $\mathrm{X}$ & $\mathrm{x}$ & $\mathrm{x}$ & $x$ & $\mathrm{X}$ \\
\hline Greece & - & - & $\mathrm{x}$ & $\mathrm{x}$ & $\mathrm{x}$ & $\mathrm{x}$ & $\mathrm{x}$ & $\mathrm{x}$ & $\mathrm{x}$ & $\mathrm{X}$ & $\mathrm{x}$ & $\mathrm{x}$ & $\mathrm{x}$ & \\
\hline Ireland & - & - & $\mathrm{x}$ & $\mathrm{x}$ & $\mathrm{x}$ & $\mathrm{x}$ & $\mathrm{x}$ & $\mathrm{x}$ & $\mathrm{x}$ & $\mathrm{X}$ & $\mathrm{x}$ & $\mathrm{x}$ & $\mathrm{x}$ & $\mathrm{X}$ \\
\hline Italy & $\mathrm{x}$ & $\mathrm{x}$ & $\mathrm{x}$ & $\mathrm{x}$ & $\mathrm{x}$ & $\mathrm{x}$ & $\mathrm{x}$ & $\mathrm{x}$ & $\mathrm{x}$ & $\mathrm{X}$ & $\mathrm{x}$ & $\mathrm{x}$ & $\mathrm{x}$ & $\mathrm{X}$ \\
\hline Luxembourg & $\mathrm{x}$ & $\mathrm{x}$ & $\mathrm{x}$ & $\mathrm{x}$ & $\mathrm{x}$ & $\mathrm{x}$ & $\mathrm{x}$ & $\mathrm{x}$ & $\mathrm{x}$ & $\mathrm{X}$ & $\mathrm{x}$ & $\mathrm{x}$ & $\mathrm{x}$ & \\
\hline Portugal & $\mathrm{x}$ & $\mathrm{x}$ & $\mathrm{x}$ & $\mathrm{x}$ & $\mathrm{x}$ & $\mathrm{x}$ & $\mathrm{x}$ & $\mathrm{x}$ & $\mathrm{x}$ & $\mathrm{x}$ & $\mathrm{x}$ & $\mathrm{x}$ & $\mathrm{x}$ & $\mathrm{x}$ \\
\hline Slovak Republic & & & & & $\mathrm{x}$ & $\mathrm{x}$ & $\mathrm{x}$ & $\mathrm{x}$ & $\mathrm{x}$ & $\mathrm{X}$ & $\mathrm{x}$ & $\mathrm{x}$ & $\mathrm{x}$ & $\mathrm{x}$ \\
\hline Slovenia & $\mathrm{x}$ & $\mathrm{x}$ & $\mathrm{x}$ & $\mathrm{x}$ & $\mathrm{x}$ & $\mathrm{x}$ & $\mathrm{x}$ & $\mathrm{x}$ & $\mathrm{x}$ & $\mathrm{X}$ & $\mathrm{x}$ & $\mathrm{x}$ & $\mathrm{x}$ & $\mathrm{x}$ \\
\hline Spain & $\mathrm{x}$ & $\mathrm{x}$ & $\mathrm{x}$ & $\mathrm{x}$ & $\mathrm{x}$ & $\mathrm{x}$ & $\mathrm{x}$ & $\mathrm{x}$ & $\mathrm{x}$ & $\mathrm{X}$ & $\mathrm{x}$ & $\mathrm{x}$ & $\mathrm{x}$ & $\mathrm{x}$ \\
\hline
\end{tabular}

\subsection{Discussion}

Regarding control variables, the results include a statistically significant negative effect of population growth (POP_GR) on GDP growth (GDP_GR) ( $\beta$ between -0.89 and -1.03 ). In addition, we found a statistically significant positive association of growth in the number of working hours (POP_GR) with GDP growth (GDP_GR) ( $\beta$ between 0.93 and 0.98). Models 1, 3, and 4 (i.e., the overall sample) show a statistically significant negative effect of GDP per capita (GDP_PC) on GDP growth (GDP_GR). In this regard, it is worth noting that labor productivity provides a measure of the efficiency with which a unit of labor input can produce goods and services, which can be assessed in various ways (Kameda, 2009). As pointed out by Salim (1999), this is a variable that quantifies productivity and consequently reflects economic growth. Thus, the larger the number of working hours, the higher the GDP rises or the stronger economic growth becomes (Nakamura et al., 2019).

The results for environmental patents' effect on the prediction of real GDP growth reveal a statistically significant mediating impact of countries' location on the relationship of environmental patents (PAT_ENVxEURO) with real GDP growth (GDP_GR) $(\beta=0.04 ; p<$ 0.01 ). That is, European countries show a statistically significant positive relationship between environmental patents (PAT_ENV) and real GDP growth (GDP_GR) $(\beta=0.03 ; p<0.05)$, but, in the Eurozone, this link is not statistically significant $(\beta=0.04 ; p \geq 0.05)$. According to the results of model 8, environmental management patents (PAT_ENV_MAN) have no statistically significant association with real GDP growth (GDP_GR) in any of the models, and countries' location-in the Eurozone or the rest of Europe-has no mediating effect on this relationship (PAT_ENV_MANxEURO). In terms of water-related adaptation technology patents (PAT_ENV_WAT), the results show a statistically significant influence of these patents in all countries $(\beta=0.44 ; p$ $<0.05)$, Eurozone countries $(\beta=1.16 ; p<0.05)$, and European countries $(\beta=0.33 ; p<0.05)$. Thus, the first hypothesis (i.e., H1: Sustainable technology transfer has a positive impact on economic growth) is confirmed. Although some differences were detected between the countries under study (i.e., in the Eurozone and rest of

Table 2

Variables used in analyses.

\begin{tabular}{|c|c|c|c|}
\hline Variables & Units & Authors & Hypotheses \\
\hline \multicolumn{4}{|l|}{ Dependent Variable } \\
\hline Real GDP growth (GDP_GR) & Annual growth in percentage & Chen and Quang, (2014); Ouardighi, (2011) & \\
\hline \multicolumn{4}{|l|}{ Predictor Variables } \\
\hline \multicolumn{4}{|l|}{ Control Variables } \\
\hline European country (EUR) & $\begin{array}{l}\text { 1: European country; } 0: \\
\text { Eurozone country }\end{array}$ & $\begin{array}{l}\text { Chen and Quang, (2014); Groningen Growth \& Development Center } \\
\text { (2009); Quinn (1997); Ouardighi (2011) }\end{array}$ & \\
\hline Population growth rates (POP_GR) & Annual growth in percentage & & \\
\hline GDP per capita (GDP_PC) & $\begin{array}{l}\text { In thousands of } € \text { and constant } \\
\text { prices }\end{array}$ & & \\
\hline Current account balance (CAB) & Percentage of GDP & & \\
\hline Total hours worked growth (THW_GR) & Annual growth in percentage & & \\
\hline \multicolumn{4}{|c|}{ Sustainable Technology Transfer (Patent Variables) } \\
\hline $\begin{array}{l}\text { Selected environment-related technologies patents } \\
\quad \text { (PAT_ENV) }\end{array}$ & Per million inhabitants & Ferreira et al. (2018); Ferreira et al. (2019); Peres-Ortiz et al. (2018) & $\mathrm{H} 1$ \\
\hline $\begin{array}{l}\text { Environmental management patents } \\
\quad \text { (PAT_ENV_MAN) }\end{array}$ & Per million inhabitants & & \\
\hline $\begin{array}{l}\text { Water-related adaptation technologies patents } \\
\text { (PAT_ENV_WAT) }\end{array}$ & Per million inhabitants & & \\
\hline \multicolumn{4}{|l|}{ Climate Change Mitigation Technology } \\
\hline Climate change mitigation patents (PAT_ENV_CLIM) & Per million inhabitants & Ferreira et al. (2018); Ferreira et al. (2019); Peres-Ortiz et al. (2018) & H2 \\
\hline
\end{tabular}


Table 3

Correlation matrix for exogenous variables used in empirical analyses.

\begin{tabular}{|c|c|c|c|c|c|c|c|c|c|c|c|c|}
\hline Variable & Mean & SD & 1 & 2 & 3 & 4 & 5 & 6 & 7 & 8 & 9 & 10 \\
\hline GDP_GR & 1.93 & 3.15 & $\mathrm{NC}$ & & & & & & & & & \\
\hline POP_GR & 0.54 & 0.64 & 0.05 & 2.33 & & & & & & & & \\
\hline GDP_PC & 36.99 & 13.47 & -0.03 & 0.58 & 3.61 & & & & & & & \\
\hline $\mathrm{CAB}^{-}$ & -0.08 & 6.5 & -0.09 & 0.15 & 0.68 & 2.43 & & & & & & \\
\hline THW_GR & 0.39 & 2.47 & 0.68 & 0.32 & 0.24 & 0.05 & 1.13 & & & & & \\
\hline EUR & 0.92 & 0.28 & -0.09 & -0.36 & 0.03 & 0.20 & -0.12 & 1.29 & & & & \\
\hline PAT_ENV & 22.54 & 20.32 & -0.15 & 0.04 & 0.48 & 0.58 & 0.02 & 0.15 & 1.61 & & & \\
\hline PAT_ENV_MAN & 11.19 & 9.84 & -0.04 & 0.05 & 0.52 & 0.59 & 0.09 & 0.16 & 0.87 & 1.74 & & \\
\hline PAT_ENV_WAT & 0.95 & 1.02 & -0.08 & 0.15 & 0.39 & 0.53 & 0.08 & -0.01 & 0.61 & 0.52 & 3.15 & \\
\hline PAT_ENV_CLIM & 15.86 & 15.82 & -0.17 & 0.03 & 0.43 & 0.52 & -0.01 & 0.14 & 0.98 & 0.78 & 0.57 & 1.72 \\
\hline
\end{tabular}

Notes: VIF in bold on diagonal; NC = not computed; SD = standard deviation.

Europe) regarding environmental patents, in general, the variables related to sustainable technology transfer have a positive effect on economic growth. In this regard, it is worth noting that various authors argue that climate change in recent decades is evidence of the environmental degradation caused by humans pursuing economic growth and expanding populations that exploit natural resources to the limit. These trends have led countries to overestimate their technological achievements and ignore their limitations (Bertinelli et al., 2012; Clow, 1998; Coccia, 2014). The environmental effects caused by economic activities that consume natural resources are only one of the problems that various researchers predict will lead to the collapse of social, biological, and economic systems during the second half of the twenty-first century (Tsiliyannis, 2014). Ayres (1996) raises a number of questions about the categories of technological innovations that would be necessary to guarantee a truly sustainable future and that scientific and technological progress must also be part of the equation.

Furthermore, the environmental dimension of sustainability, an ecoinnovation perspective has emerged in response to the need to reduce the use of multiple resources and sources. This can be done by incorporating new and different technologies rather than introducing innovative applications of older technologies (Huber, 2000). Montalvo (2008) focused on how sustainable innovations have rapidly expanded and a deeper understanding of the ways new clean technologies and social practices, such as eco-innovation, promote technological, institutional, and organizational knowledge of existing production systems should be a priority for a sustainable economic growth.

Regardless of this expanding pool of knowledge, Coenen and Díaz López (2010) suggest that the concept of eco-innovation reveals the tension between the diverse motivations behind economically-oriented objectives, ecological modernization, and social functions. Technological innovations can be seen as a way to optimize the efficient, clean use of vital resources in social, biological, and economic systems (Cancino et al., 2018). The present study's results further reinforce the body of research confirming that economic growth is possible without destroying the environment, provided that progress is achieved through innovations and the transfer of sustainable knowledge.

Regarding the effect of climate change mitigation patents (PAT_ENV_CLIM) on real GDP growth, the results show a statistically significant mediating impact of countries' location on the relationship between these patents (PAT_ENV_CLIMxEURO) and real GDP growth (GDP_GR) $(\beta=0.04 ; p<0.05)$. This means that, in both Eurozone countries and the rest of Europe, a statistically significant positive link exists between climate change mitigation patents (PAT_ENV_CLIM) and real GDP growth (GDP_GR) $(\beta=0.04 ; p<0.05)$. Therefore, the second hypothesis (i.e., H2: Climate change mitigation technology has a positive impact on economic growth) is confirmed. Wiesenthal et al. (2012) study found that aggregate research and development (R\&D) investments devoted to low-carbon energy technologies amounted to $€ 3.3$ billion in the EU. This amount came mainly from public funding from EU member states and the industrial research activities of companies registered in the EU. However, gaining access to public climate change mitigation funds is not always easy. Lettice et al. (2012) found evidence of this challenge during an analysis of the factors associated with fund allocation decisions. The cited researchers confirmed that, despite funding agencies' clear intentions and expectations, the allocation of funds is not always linear. That is, even though carbon reduction is a priority, this is not a significant factor when organizations allocate funds to candidate projects.

Climate change mitigation can also have other advantages. For instance, new market opportunities and jobs have been created due to the increasing demand for low-carbon and other environmental technologies. Fankhaeser et al. (2008) found that some positive impacts of efforts to alleviate the effects of climate change are job creation, innovation, and economic growth. Thus, a link exists between green innovations and employment, which is stronger for companies that introduce these innovations voluntarily (Kunapatarawong and Martínez-Ros, 2016). The present study's results, therefore, confirm that organizations can mitigate climate change effects while contributing to economic growth.

\section{Conclusions and implications}

This research sought to contribute to a deeper understanding of the problem of climate change and, specifically, of the effects of technology transfer, mitigation of climate change, and environmental patents on economic growth. In addition, the findings contribute to the literature on technology transfer policies by elucidating how environmental patents impact Europe's economic growth rate. Regarding environmental patents' effects, the results support the conclusion that countries' location has a mediating effect on environmental patents' link with real GDP growth. In other words, these patents have a positive influence on European countries' economic growth. However, this study was unable to verify environmental patents' positive influence on economic growth specifically within the Eurozone. In terms of water-related adaptation technology and climate change mitigation patents, the evidence shows that both types significantly influence economic growth in European countries.

According to Cancino et al. (2018), countries' sustainable value can be evaluated in three dimensions. The first is policies that enhance environmental value, which comprises renewable resources, low emissions, low waste, biodiversity, and prevention of pollution (i.e., air, water, and land). The second dimension is the forms of social value implemented, including equality and diversity, wellbeing, community development, safe livelihoods, labor standards, and health and safety. The last dimension is forms of economic value, which involve profit, return on investment, financial resilience, and long-term viability. This kind of systemic approach is fundamental whenever researchers seek to integrate sustainability into business models from a global perspective, as well as incorporating systems' different elements and their interrelationships. While wellbeing implies economic power for growing populations, wellbeing also means improved health, education, and cultural life and a better overall standard of living. 


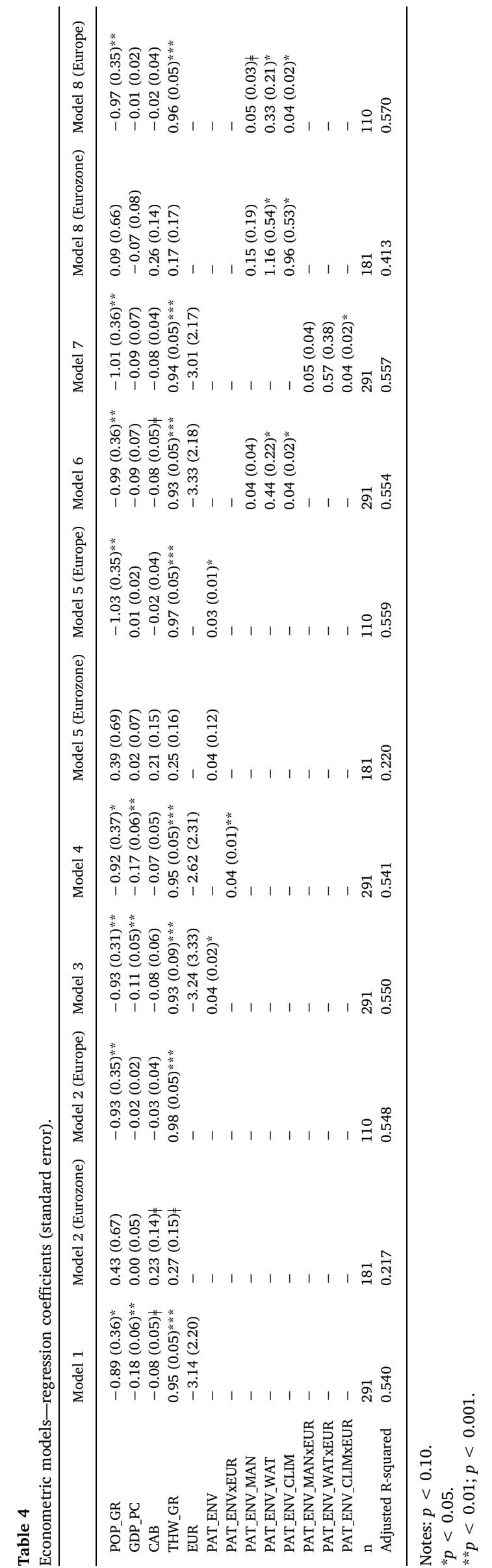

Bertinelli et al. (2012) argue that, currently, the aggregation of wealth alone clearly does not result in a sufficient reduction of environmental pollution or in all populations having equal access to a higher standard of living. In addition, Rochon et al. (2010) assert that improved policies and practices at the corporate, academic, and government levels are crucial to preventing global collapse and promoting sustainable growth.

Given the dilemmas generated by combining economic development and sustainable growth, technological innovations can be seen as solutions by those seeking to generate environmentally friendly conditions throughout the production of goods and services. However, experts also recognize that technological innovations require political guidance that orchestrates ecological modernizations, as these do not spontaneously develop in the right direction (Lorek and Spangenberg, 2014; Nielsen et al., 2015). Environmental, social, and economic concerns about innovation have become more common because countries are now aware of their activities' consequences, and many nations seek to be socially responsible.

Innovations at all levels and from different sources generate push and pull forces that must be balanced when considering a transition to more sustainable forms of production. Technological capabilities have an important national dimension as countries regularly dedicate significant resources to developing and maintaining these competencies. As the present results show, at least apparently, there is no conflict between improving technological capabilities and placing emphasis on sustainability and welfare.

Nonetheless, R\&D, which is a strong driver of technological innovation, cannot avoid an imminent collapse without fundamental changes in societies' dominant values of growth, exploitation and consumption. This complex, urgent need can only be met by first recognizing organizations' lack of experience in creating policies in this area. The present study's findings could thus facilitate the creation of guidelines for technology transfer and innovation that mitigate climate change and promote economic growth.

Given that the transfer of climate change-related innovation has increased in recent years, the following becomes a legitimate question: How can this diffusion be further accelerated? The present results do not include an evaluation of different policies' potential, yet regulations are obviously a factor that fosters the creation of markets for environmentally sound technologies and encourages companies to acquire new technologies. This conclusion is supported by Lanjouw and Mody (1996), who established that strict regulations for vehicle emissions in the United States has led to, for example, up-to-date technology transfer from Japan and Germany to the United States. The adoption of stricter regulations in Finland and Sweden's pulp and paper industry has also triggered an increase in the use of chlorine-free technology (Popp et al., 2007).

Technological development requires investment from both the public and private sectors. Public sector R\&D has been an important catalyst in the development of twenty-first century technologies, including aeronautics, electronics, and nuclear energy. Public R\&D should also play a role in the transition to low-carbon energy technologies. Environmentally friendly technologies have been developed in response to explicit, strong government support in the form of tax incentives, R\&D subsidies, favorable regulatory frameworks, and government expenditure policies.

On the one hand, extensive public participation in these technologies could provide governments with sufficient leverage to disseminate innovations more widely to serve the greater public interest. On the other hand, these policies may ultimately end up increasing nations' competitiveness, which can work in opposition to the objective of facilitating technology transfer and, more specifically, the transfer of sustainable technology. In the future, greenhouse gas emission reduction targets will be key to stimulating private sector investment in R\&D. To achieve cost reduction, a large-scale deployment of low-carbon technologies will be critical. Thus, human resources and institutional development are crucial to facilitating the use of technology. 
Institutional development includes generating the capacity to adopt new technologies that enhance business valuation.

Country-level climate change mitigation and adaptation capabilities can be improved when environment technology policies are integrated into national sustainable development strategies. These technological capabilities promote innovation, thereby improving access to markets and strengthening competitiveness. In conclusion, the most significant driver of climate change mitigation powerful enough to confront corporate power may not be either climate change itself or even environmental quality standards. Instead, the primary engine could be the economic development and growth associated with efforts to minimize and reverse climate change.

As with any other study, it is important to note that there are limitations that should be acknowledged and considered in future research. Specifically, our study is based only on secondary data and focuses solely on European countries. As such, future research might want to apply our framework in other contexts, use primary data and/or include other variables and dimensions. Additional research on how different forms of stakeholders influence impact the process of sustainable entrepreneurship also seems to be an important point to be addressed. This would help to clarify, for instance, how firms are utilizing patents as a way to start new business ventures or how different policy factors may influence environmental related patents. Any contribution in this regard would be a welcome addition to this study.

\section{Acknowledgement}

This work was supported by the Portuguese Foundation for Science and Technology (Grants UID/GES/04630/2019 and UID/GES/00315/ 2013).

\section{References}

Albrizio, S., Kozluk, T., Zipperer, V., 2017. Environmental policies and productivity growth: evidence across industries and firms. J. Environ. Econ. Manage. 81, 206-226. Antonioli, D., Mancinelli, S., Mazzanti, M., 2013. Is environmental innovation embedded within high-performance organisational changes? the role of human resource management and complementarity in green business strategies. Res. Policy 42, 975-988.

Ashford, N., Ayers, C., Stone, R., 1985. Using regulation to change the market for in novation. Harvard Environ. Law Rev. 9 (2), 419-466.

Ayres, R., 1996. Technology, progress and economic growth. Eur. Manage. J. 14 (6), 562-575.

Bagatin, R., Kleme, J., Reverberi, A., Huisingh, D., 2014. Conservation and improvements in water resource management: a global challenge. J. Clean Prod. 77 (15), 1-9.

Barron, R., McJeon, H., 2015. The differential impact of low-carbon technologies on climate change mitigation cost under a range of socioeconomic and climate policy scenarios. Energy Policy 80, 264-274.

Bayarçelik, E., Taşel, F., 2012. Research and development: source of economic growth Procedia-Social and Behavioral Sciences 58, 744-753.

Bektas, C., Pece, A., Simona, O., Salisteanu, F., 2015. Innovation and economic growth: an empirical analysis for cee countries. Procedia Econ. Finance 26, 461-467.

Bell, M., 2012. International technology transfer, innovation capabilities and sustainable directions of development. In: Ockwell, D., Mallett, A. (Eds.), Low-Carbon Technology Transfer: From Rhetoric to Reality. Routledge, pp. 346-374.

Bertinelli, L., Strobl, E., Zou, B., 2012. Sustainable economic development and the environment: theory and evidence. Energy Econ. 34 (4), 1105-1114.

Blazejczak, J., Edler, D., Hemmelskamp, J., Jänicke, M., 2000. Innovation-oriented environmental regulation. In: Hemmelskamp, J., Rennings, K., Leone, F. (Eds.), Environmental Policy and Innovation: An International Comparison of Policy Frameworks and Innovation Effects. ZEW Economic Studies, pp. 125-152.

Boons, F., Montalvo, C., Quist, J., Wagner, M., 2013. Sustainable innovation, business models and economic performance: an overview. J. Clean Prod. 45, 1-8.

Cainelli, G., De Marchi, V., Grandinetti, R., 2015. Does the development of environmental innovation require different resources? Evidence from Spanish manufacturing firms. J. Clean Prod. 94, 211-220.

Cancino, C, La Paz, A, Ramaprasad, A, Syn, T., 2018. Technological innovation for sustainable growth: an ontological perspective. J. Clean Prod. 179, 31-41.

Chaudhry, R., Fischlein, M., Larson, J., Hall, D., Peterson, T., Wilson, E., Stephens, J., 2013. Policy stakeholders' perceptions of carbon capture and storage: a comparison of four US states. J. Clean Prod. 52, 21-32.

Chege, M., Wang, D., Suntu, L., Bishoge, K., 2019. Influence of technology transfer on performance and sustainability of standard gauge railway in developing countries. Technol. Soc. https://doi.org/10.1016/j.techsoc.2018.09.007.

Chen, J., Quang, T., 2014. The impact of international financial integration on economic growth: New evidence on threshold effects. Econ. Model. 42, 475-489.
Clow, M., 1998. The natural limits of technological innovation. Technol. Soc. 20 (2), 141-156.

Coccia, M., 2014. Driving forces of technological change: the relation between population growth and technological innovation analysis of the optimal interaction across countries. Technol. Forecasting Social Change 82, 52-65.

Coenen, L., Díaz López, F, 2010. Comparing systems approaches to innovation and technological change for sustainable and competitive economies: an explorative study into conceptual commonalities, differences and complementarities. J. Clean Prod. 18, 1149-1160.

Costantini, V., Liberati, P., 2014. Technology transfer, institutions and development. Technol. Forecasting Social Change 88, 26-48.

De Marchi, V., Grandinetti, R., 2013. Knowledge strategies for environmental innovations: the case of Italian manufacturing firms. J. Knowl. Manage. 17 (4), 569-582.

Dong, Y., Wang, X., Jin, J., Qiao, Y., Shi, L., 2014. Effects of eco-innovation typology on its performance: empirical evidence from chinese enterprises. J. Eng. Technol. Manage. 34, 78-98.

EPA-Environmental Protection Agency. 2016. Global greenhouse gas emissions data. Retrieved September 17, 2018, from. https://www3.epa.gov/climatechange/ghgemissions/global.html.

Fabrizi, A., Guarini, G., Meliciani, V., 2018. Green patents, regulatory policies and research network policies. Res. Policy 47 (6), 1018-1031.

Fagerberg, J., 1994. Technology and international differences in growth rates. J. Econ. Lit. 32, 1147-1175.

Fankhaeser, S., Sehlleier, F., Stern, N., 2008. Climate change, innovation and jobs. Climatic Policy 8, 421-429.

Ferreira, J, Fernandes, C, Ratten, V., 2019. The effects of technology transfers and institutional factors on economic growth: evidence from Europe and Oceania. J. Technol. Transfer. https://doi.org/10.1007/s10961-019-09730-3.

Ferreira, J., Fernandes, C, Ratten, V., 2018. World journal of entrepreneurship. Environmental-Related Patent Technology Transfer Effectiveness: A comparison Between Portugal and Australia using OECD Data 14. Management and Sustainable Development, pp. 206-221.

Freeman, C., 2002. Continental, national and sub-national innovation systems: complementarity and economic growth. Res. Policy 31, 191-211.

GGDC - Groningen Growth \& Development Center. 2009. The Conference Board Total Economy Database, Groningen Growth and Development Centre. Retrieved September 17, 2018, from http://www.conferenceboard.org/economics.

Global Mobility Report, 2017. Tracking Sector Performance. Washington, DC

Goodall, A., 2008. Why have the leading journals in management (and other social sciences) failed to respond to climate change. J. Manage. Inquiry 17, 408-420.

Grimsley, S. 2016. What is sustainable economic growth? definition \& overview. Retrieved September 18, 2018, from http://study.com/academy/lesson/what-issustainable-economic-growth-definition-lesson-quiz.html.

Grossman, G., Helpman, E., 1994. Endogenous innovation in the theory of growth. J. Econ. Perspect. 8 (1), 23-44.

Grossman, G., Krueger, A., 1995. Economic growth and the environment. Q. J. Econ. 110, 353-377.

Grubb, M., 2004. Technology Innovation and Climate Change Policy: An overview of Issues and Options 41. Keio Economic Studies, pp. 103-132.

Hall, J., Clark, W., 2003. Special issue: environmental innovation. J. Cleaner Prod. 11 (4), 343-346.

Hasan, I., Tucci, C., 2010. The innovation-economic growth nexus: global evidence. Res Policy 39, 1264-1276.

Haselip, J., Hansen, U., Puig, D., Trærup, S., Dhar, S., 2015. Governance, enabling frameworks and policies for the transfer and diffusion of low carbon and climate adaptation technologies in developing countries. Climatic Change 131, 363-370.

Huber, J., 2000. Towards industrial ecology: sustainable development as a concept of ecological modernization. J. Environ. Policy Plan. 2 (4), 269-285.

Jaffe, A., Palmer, K., 1997. Environmental regulation and innovation: a panel data study. Rev. Econ. Stat. 79, 610-619.

Jong, S., Wardenaar, T., Horlings, E., 2016. Exploring the promises of transdisciplinary research: a quantitative study of two climate research programmes. Res. Policy 45, 1397-1409.

Kameda, S., 2009. Issues On Japan's productivity: How do We Evaluate Productivity Developments Since 2000? Bank of Japan Working Paper Series.

Keller, W., 2010. International trade, foreign direct investment, and technology spillovers. Handbook Econ. Innovation 2, 793-829.

Kunapatarawong, R., Martínez-Ros, E., 2016. Towards green growth: how does green innovation affect employment? Res. Policy 45, 1218-1232.

Lanjouw, J., Mody, A., 1996. Innovation and the international diffusion of environmentally responsive technology. Res. Policy 25, 549-571.

Lettice, F., Smart, P., Baruch, Y., Johnson, M., 2012. Navigating the impact-innovation double hurdle: the case of a climate change research fund. Res. Policy 41, 1048-1057.

Lorek, S., Spangenberg, J., 2014. Sustainable consumption within a sustainable economy: beyond green growth and green economies. J. Clean Prod. 63, 33-44.

Lundvall, B., 2011. Notes on innovation systems and economic development. Innovation Dev. 1 (1), 25-38.

Matos, S., Silvestre, B., 2013. Managing stakeholder relations when developing sustainable business models: the case of the Brazilian energy sector. J. Clean Prod. 45, 61-73.

McSweeney, R., \& Pidcock, R. 2015. Scientists discuss the 1.5C limit to global temperature rise. carbon brief. Retrieved September 17, 2018, from https://www.carbonbrief org/scientistsdiscuss-the-1-5c-limit-to-global-temperature-rise.

Montalvo, C., 2008. General wisdom concerning the factors affecting the adoption of cleaner technologies: a survey 1990-2007. J. Clean Prod. 16, S7-S13.

Moss, R., Edmonds, J., Hibbard, K., Manning, M., Rose, S., Van Vuuren, D., Wilbanks, T., 
2010. The next generation of scenarios for climate change research and assessment. Nature 463, 747-756.

Mowery, D., Nelson, R., Martin, B., 2010. Technology policy and global warming: why new policy models are needed (or why putting new wine in old bottles won't work Res. Policy 39, 1011-1023.

Mytelka, L., 2007. Technology Transfer Issues in Environmental Goods and services. An Illustrative Analysis of Sectors Relevant to Air-Pollution and Renewable energy. ICTSD Programme on Trade and Environment. United Nations University-Maastricht Economic and Social Research and Training Centre on Innovation and Technology (UNU-MERIT).

Nakamura, K., Kaihatsu, S., Yagi, T., 2019. Productivity improvement and economic growth: lessons from Japan. Econ. Anal. Policy 62, 57-79.

Nielsen, K., Nielsen, K., Reisch, L., 2015. Reality test: Users, Innovation and Sustainability (European policymakers' View On Sustainable User Innovation and Entrepreneurship). Copenhagen Business School.

Nino, F., 2016. United Nations Sustainable Development Goals-Goal 8: Promote Inclusive And Sustainable Economic Growth, Employment and Decent Work For All. United Nations.

Norberg-Bohm, V., 1999. Stimulating "green" technological innovation: an analysis of alternative policy mechanisms. Policy Sci. 32 (1), 13-38.

Ockwell, D., Mallet, A., Urban, F., 2013. Low Carbon Innovation and Technology Transfer. In: Nordensvärd, J. (Ed.), Low carbon development: Key issues, Routledge (p. xxii).

Ockwell, D., Watson, J., MacKerron, G., Pal, P., Yamin, F., 2008. Key policy considerations for facilitating low carbon technology transfer to developing countries. Energy Policy 36, 4104-4115.

Oreskes, N., 2004. Beyond the ivory tower: the scientific consensus on climate change. Science 306, 1686.

Ouardighi, J., 2011. Pro-development economic growth and international income mobility: Evidence worldwide. Int. Econ. 128, 77-96.

Owen, R., Bessant, J., Heintz, M., 2013. Responsible innovation: Managing the Responsible Emergence of Science and Innovation in Society. John Wiley \& Sons, Ltd.

Peres-Ortiz, M., Ferreira, J., Fernandes, C., 2018. Do total early-stage entrepreneurial activities (TEAs) foster innovative practices in oecd countries. Technol. Forecasting Social Change 129, 176-184.

Peters, M., Schneider, M., Griesshaber, T., Hoffmann, V., 2012. The impact of technologypush and demand-pull policies on technical change: does the locus of policies matter. Res. Policy 41, 1296-1308.

Popp, D., Hafner, T., \& Johnstone, N. 2007. Policy vs. consumer pressure: innovation and diffusion of alternative bleaching technologies in the pulp industry. Retrieved September 17, 2018, from http://ssrn.com/abstract $=1016350$.

Porter, M., Van der Linde, C., 1995. Toward a new conception of the environment competitiveness relationship. J. Econ. Perspect. 9, 97-118.

Quinn, D., 1997. The correlates of change in international financial regulation. Am. Polit. Sci. Rev. 91, 531-551.

Rochon, G., Niyogi, D., Fall, S., Quansah, J., Biehl, L., Araya, B., Thiam, T., 2010. Best management practices for corporate, academic and governmental transfer of sustainable technologies to developing countries. Clean Technol. Environ. Policy 12 (1), 9-30.

Salim, R., 1999. Capacity Realization and Productivity Growth in a Developing country: Has economic Reform Had impact? Ashgate Publishing Company, UK.

Segerstrom, P., 1991. Innovation, imitation, and economic growth. J. Polit. Econ. 99, 807-827.

Solomon, S., Plattner, G., Knutti, R., Friedlingstein, P., 2009. Irreversible climate change due to carbon dioxide emissions. proceedings of the national. Acad. Sci. United States Am. 106 (6), 1704-1709.

Solow, R., 1956. A contribution to the theory of economic growth. Q. J. Econ. 70 (1), 65-94.

Stahl, B., Eden, G., Jirotka, M., 2013. Responsible research and innovation in information and communication technology: identifying and engaging with the ethical implications of ICTs. In: Owen, R., Bessant, J., Heintz, M. (Eds.), Responsible Innovation: Managing the Responsible Emergence of Science and Innovation in Society. John Wiley \& Sons, Ltd, pp. 199-218.

Su, H., Moaniba, I., 2017. Does innovation respond to climate change? Empirical evidence from patents and greenhouse gas emissions. Technol. Forecasting Social Change 122, $49-62$.
Tsiliyannis, C., 2014. Cyclic manufacturing: necessary and sufficient conditions and minimum rate policy for environmental enhancement under growth uncertainty. J. Clean Prod. 81, 16-33.

Tucker, M., 1995. Carbon dioxide emissions and global GDP. Ecol. Econ. 15, 215-223.

UNCTC-United Nations Center on Transnational Corporations, 1987. Transnational Corporations and Technology transfer: Effects and Policy Issues. United Nations Centre on Transnational Corporations.

UNCTD-United Nations Conference on Trade and Development, 2010. World Investment Report 2010: Investing in a Low-Carbon Economy. United Nations Conference on Trade and Development.

UNFCCC-United Nations Framework Convention on Climate Change. 2015. Historic paris agreement on climate change 195 nations set path to keep temperature rise well below $2{ }^{\circ}$ CelsiusRetrieved September 17, 2018, from. http://newsroom.unfccc.int/ unfccc-newsroom/finale-cop21/.

Veugelers, R., 2012. Which policy instruments to induce clean innovating? Res. Policy 41, $1770-1778$.

Voegtlin, C., Scherer, A., 2017. Responsible innovation and the innovation of responsibility: governing sustainable development in a globalized world. J. Bus. Ethics 143 (2), 227-243.

Von Schomberg, R., 2011. Towards Responsible Research and Innovation in the Information and Communication Technologies and Security Technologies Fields. European Commission-DG Research and Innovation.

Watson, J., Byrne, R., Ockwell, D., Stua, M., 2015. Lessons from China: building technological capabilities for low carbon technology transfer and development. Clim. Change 131, 387-399.

Wennersten, R., Sun, Q., Li, H., 2015. The future potential for carbon capture and storage in climate change mitigation: an overview from perspectives of technology, economy and risk. J. Clean Prod. 103, 724-736.

Wiesenthal, T., Leduc, G., Haegeman, K., Schwarz, H., 2012. Bottom-up estimation of industrial and public R\&D investment by technology in support of policy-making: the case of selected low-carbon energy technologies. Res. Policy 41, 116-131.

Wong, P., Ho, Y., Autio, E., 2005. Entrepreneurship, innovation and economic growth: evidence from GEM data. Small Bus. Econ. 24, 335-350.

Youssef, A., Boubaker, S., Omri, A., 2018. Entrepreneurship and sustainability: the need for innovative and institutional solutions. Technol. Forecasting Social Change 129, 232-241.

Zollo, M., Cennamo, C., Neumann, K., 2013. Beyond what and why: understanding organizational evolution towards sustainable enterprise models. Organ. Environ. 26 (3), 241-259.

Joà J. M. Ferreira is Associate Professor at the University of Beira Interior (UBI), Portugal. He holds a PhD in Entrepreneurship and Small Business Management from the Autonomous University of Barcelona (UAB), Spain. Currently, he is the scientific coordinator of the UBI Research Unit for Business Sciences (NECE), Portugal. He has pub lished over 200 papers in premier international journals, and edited or co-edited several books on innovation and entrepreneurship. His-research interests include strategy, competitiveness and entrepreneurship.

Cristina I. Fernandes is Assistant Professor at the University of Beira Interior (UBI), Portugal. She is researcher member at NECE- Research Centre in Business Sciences, University of Beira Interior (UBI). Her research interests include knowledge intensive business services, innovation, competitiveness and entrepreneurship. She has published several papers in international journals.

Fernando A. F. Ferreira is Vice-Dean for financial affairs at the ISCTE Business School of the University Institute of Lisbon, Portugal, and Adjunct Research Professor at the Fogelman College of Business and Economics of the University of Memphis, TN, USA. He holds a PhD in Quantitative Methods Applied to Economics and Management from the University of Algarve, Portugal. Some of his articles are published by ISI-listed journals such as Journal of the Operational Research Society, Journal of Business Research, Management Decision, Service Business, and International Journal of Information Technology \& Decision Making. He has practical experience as group facilitator and his research interests include multiple criteria decision analysis, fuzzy logics and integrated systems for performance measurement. 